\title{
CARMINA ANACREONTEA
}

Mauricio López Noriega*

Los Carmina Anacreontea, esas 'encantadoras y dulces elegías amorosas', 1 conforman una colección de poemas escritos en griego antiguo por autores anónimos que imitan a Anacreonte, poeta lírico del siglo vi a. de C. quien, por su talento, mereció en vida el honor de que se colocara una efigie suya en la acrópolis de Atenas. Henri Estienne (Stephanus) descubre la colección y la edita en París en 1554. El éxito es fulgurante; desde entonces hasta ahora, son innumerables las ediciones, reediciones, traducciones e imitaciones que se hicieron de estas poesías: Ronsard, Goethe, Quevedo, Góngora, Molière, Voltaire, Lodge, Herrick, Cowley, Leopardi, Bécquer, José Martí y Marguerite Yourcenar, entre otros, gustaron y se ocuparon de estos poemas.

Son sesenta poesías en metro llamado 'anacreóntico' cuya temática trata de reproducir la del poeta clásico; se pueden percibir, en quienes la escribieron, influencias de los estoicos, de la segunda sofística y de algunos otros movimientos de menor importancia del helenismo tardío. La presencia de la naturaleza, el binomio irreconciliable juventudsenectud, la admiración por la belleza, el claro contraste con la poesía épica y las fuerzas que representan en la vida el amor y el vino, temas dominantes, otorgan a los poemas una nota universal, deleitable.

* Departamento Académico de Estudios Generales, ITAM.

${ }^{1}$ Aulo Gelio, XIX, ix, 4: <l egêa... erotica dulcia et venusta. 
Su gracia, su ritmo, la materia tan accesible y humana, hicieron de esta colección un modelo fácilmente imitable para cualquier persona que sintiera afición por las letras, lo cual produjo que su influencia haya sido permanente y significativa en la historia de la literatura occidental. Su impacto alcanza incluso a la música: Cherubini, Carnicer, Blau-Chausmet.

No tengo noticia de una traducción completa de la obra en México; por motivo de espacio ofrezco aquí sólo una pequeña selección del conjunto. Traduje a partir del texto griego fijado por David A. Campbell, Greek Lyric, 1988, Cambridge, Harvard University Press, Loeb Classical Library, vol. II. 